\title{
Protein-losing Enteropathy and Malabsorption in Acute Measles Enteritis
}

\author{
J. F. B. DOSSETOR, H. C. WHITTLE
}

British Medical fournal, 1975, 2, 592-593

\section{Summary}

Gastrointestinal protein loss and xylose and lactose absorption were both abnormal in underweight children with acute measles and diarrhoea. The protein loss was equivalent to a mean absolute albumin loss of $1.68 \pm$ $0.21 \mathrm{~g} / \mathrm{day}$, while the mean one-hour blood xylose level was $0.93 \pm 0.38 \mathrm{mmol} / 1(14.0 \pm 5.7 \mathrm{mg} / 100 \mathrm{ml})$ in the acute stage and $1.71 \pm 0.43 \mathrm{mmol} / 1(25.6 \pm 6.5 \mathrm{mg} / 100 \mathrm{ml})$ after recovery $(P<0.01)$. Lactose intolerance was found in four children out of 17 tested. Thus faecal protein loss and malabsorption may contribute significantly to the development of malnutrition after measles.

\section{Introduction}

Measles is more severe in children who are underweight, ${ }^{1}$ and is often followed by kwashiorkor. ${ }^{2}{ }^{3}$ Plasma albumin falls during an attack of measles. ${ }^{4}$ At Ahmadu Bello University Hospital we found that $34 \%$ of children who presented with severe malnutrition had had measles within three months of presentation, and of these half had oedema. ${ }^{5}$

Measles may precipitate severe malnutrition by causing a decrease in intake of protein and calories; appetite is certainly depressed during the infection, and soreness of the mouth in breast-fed babies may lead to inability to suck and failure of lactation. ${ }^{1}$ Secondary infection may prolong the period of debility. Measles also produces a severe enteritis ${ }^{1}$ in children who are underweight, and chronic diarrhoea may persist for several weeks after the acute attack. In an attempt to define more precisely the association of measles with malnutrition we measured protein loss from gut and kidney and studied lactose and xylose absorption in underweight children with measles enteritis.

\section{Patients and Methods}

Twenty-eight children with acute measles diagnosed by the presence of Koplik's spots or the characteristic rash were studied. All had diarrhoea-that is, a liquid stool passed two to 10 times a day on the day before admission. Their age varied from 8 months to 4 years; 19 were weaned. Twenty-three were Hausa, three Yoruba, and two from other ethnic groups. The weights of 20 patients fell between $60 \%$ and $80 \%$ of the Harvard standard growth curve ${ }^{6}$; four patients' weights fell below $60 \%$ and four above $80 \%$ of this line. No patient had oedema. The mean serum albumin $( \pm$ S.D.) of all patients was $37 \pm 4 \mathrm{mg} / \mathrm{l}$. We considered that a child had recovered if the mother stated the child was well and there were no residual symptoms of cough or diarrhoea.

Faecal protein loss was estimated using ${ }^{59} \mathrm{Fe}$-labelled iron dextran $0 \cdot 1 \mu \mathrm{Ci} / \mathrm{Kg}$ injected intravenously. ${ }^{7}$ All stools were collected for the next three days and the plasma was sampled daily. From these data ${ }^{5} \mathrm{Fe}$ faecal clearance was calculated. As this correlates closely with

albumin excretion absolute albumin loss per day was calculated for each patient from the plasma albumin, plasma volume, and ${ }^{59} \mathrm{Fe}$ faecal clearance values.

Urine protein was measured using sulphosalicylic acid. Protein electrophoresis was performed after concentration on four of the urines with high protein values.

Lactose tolerance tests were performed using capillary blood samples. ${ }^{8}$ Lactose $2 \mathrm{~g} / \mathrm{kg}$ was given. Any stool passed within five hours of lactose administration was tested for reducing substances using Clinitest tablets.

One-hour blood xylose tests were performed using a 5-g dose of xylose. ${ }^{9}$

\section{Results}

Faecal Protein Loss.-The mean faecal ${ }^{59} \mathrm{Fe}$-labelled iron dextran clearance $( \pm$ S.D.) of five patients in the acute stage of measles was $5.7 \pm 1.95 \%$ of the plasma volume per day, and after recovery the clearance fell to $1 \cdot 49 \pm 0 \cdot 6 \%$ (fig. 1). The mean absolute albumin loss was $1 \cdot 68 \pm 0 \cdot 21 \mathrm{~g} /$ day.

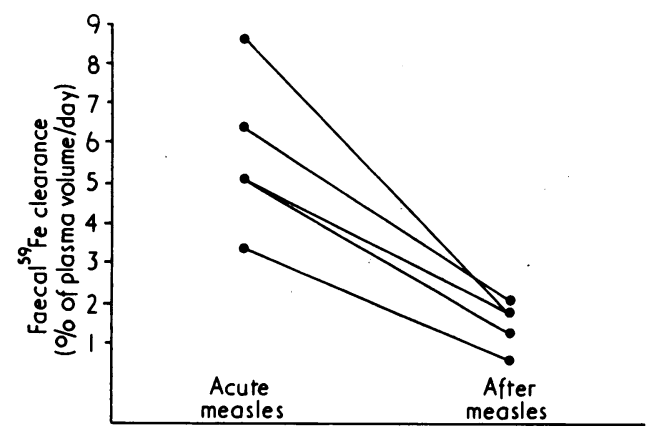

FIG. 1-Faecal clearance ${ }^{5} \mathrm{Fe}$ dextran in five patients with measles enteritis.

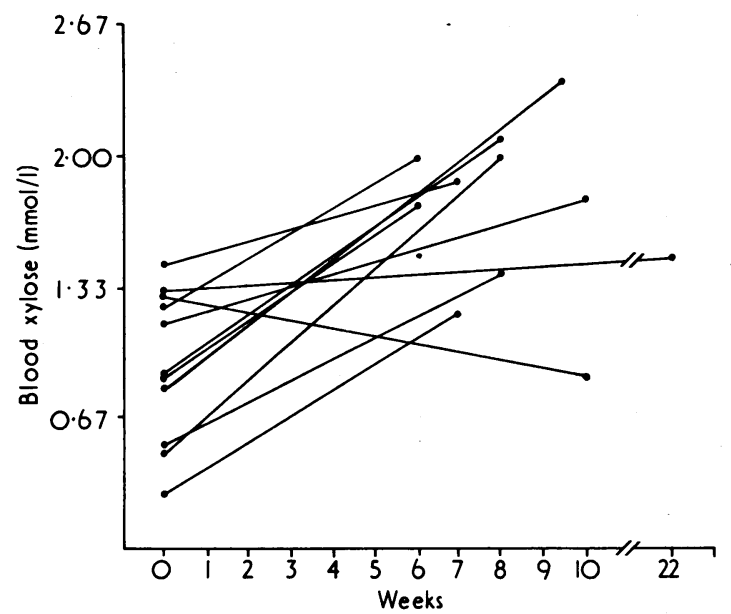

FIG. 2-One-hour blood xylose in 11 patients during measles and on recovery.

Conversion: SI to Traditional Units-Xylose: $1 \mathrm{mmol} / 1 \approx$ $15 \mathrm{mg} / 100 \mathrm{ml}$.

Urine Protein Loss. - The mean value in 22 patients with acute measles was $350 \pm 500 \mathrm{mg} / \mathrm{l}$. On recovery no patient showed urinary 
Results of Lactose Tolerance Tests in 17 Children with Acute Measles Enteritis

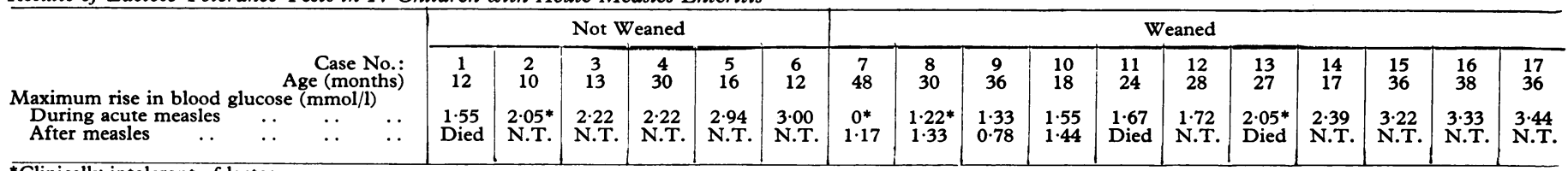

*Clinically intolerant of lactose.

N.T. $=$ Not tested.

Conversion: SI to Traditional Units-Glucose: $1 \mathrm{mmol} / 1 \approx 18 \mathrm{mg} / 100 \mathrm{ml}$.

protein. Electrophoresis showed most of the urinary protein to be albumin.

Lactose Tolerance Tests.-Tests were performed in 17 patients with acute measles (see table). Four children, three of whom were weaned, were intolerant of lactose; they had diarrhoea during the test with reducing substances in the stools. One died but the remaining three had become tolerant of lactose when retested. Blood glucose rose more than $1.67 \mathrm{mmol} / 1(30 \mathrm{mg} / 100 \mathrm{ml})$ in 11 patients. In five patients glucose rose $1 \cdot 11-1.67 \mathrm{mmol} / \mathrm{l}(20-30 \mathrm{mg} / 100 \mathrm{ml})$; two of these patients died and the other three showed no significant difference on retesting after recovery. In one patient blood glucose showed no rise during the acute illness but rose $1.17 \mathrm{mmol} / 1(21 \mathrm{mg} / 100 \mathrm{ml})$ on recovery.

Xylose Absorption Tests.-Values for 11 patients during measles and on recovery are given in fig. 2. The mean acute level was $0.93 \pm$ $0.38 \mathrm{mmol} / 1(14.0 \pm 5.7 \mathrm{mg} / 100 \mathrm{ml})$ and on recovery $1.71 \pm 0.43$ $\mathrm{mmol} / \mathrm{l}(25 \cdot 6 \pm 6.5 \mathrm{mg} / 100 \mathrm{ml})(P<0 \cdot 01)$.

\section{Discussion}

${ }^{59} \mathrm{Fe}$ dextran is used to measure gastrointestinal protein loss in children as it is not excreted in normal urine; thus contamination of faeces with radioactive urine is avoided. ${ }^{7}$ In children with proteinuria, however, whose urine and faeces cannot be collected separately significant faecal contamination might occur. We found that many children with measles did have proteinuria, but faecal contamination with urine probably had no significant effect on our results as the amount of protein excreted was small and the urinary protein excreted contained only a few plasma protein constituents with a molecular weight similar to dextran $(200000)$.

Jarnum showed that faecal ${ }^{59} \mathrm{Fe}$-labelled iron dextran clearance was closely correlated with the albumin degradation rate in patients with protein-losing enteropathy $(r=0.89$; $\mathrm{P}<0.001){ }^{7}$ The mean clearance of ${ }^{59} \mathrm{Fe}$-iron dextran in our patients was $5 \cdot 75 \%$ of the plasma volume per day. The normal disappearance of albumin (fractional catabolic rate) in adults is $9.1 \%$ per day of the total intravascular mass. ${ }^{7}$ Thus albumin turnover was almost 1.7 times greater than normal in our patients.

The mean absolute loss of albumin was $1.7 \mathrm{~g} /$ day. This quantity may be considered in relation to protein intake in, for instance, a fully breast-fed infant; if $800 \mathrm{ml}$ of breast milk is taken daily ${ }^{10}$ then protein intake from this source is $9.6 \mathrm{~g} .{ }^{11}$ Thus the albumin loss we have shown would be equivalent to about $20 \%$ of the child's normal protein intake. In practice, this intake would be reduced during measles. The importance of this loss can be further appreciated by considering that nephrotic children lose $3 \mathrm{~g}$ or more of albumin a day.
The values for ${ }^{59} \mathrm{Fe}$-labelled iron dextran clearance obtained on recovery were higher than normal $(<1 \%){ }^{7}$ Possibly normal children in Zaria have a slightly increased faecal protein loss or our patients may not have recovered completely from measles.

Though only one patient had no rise in blood glucose after the lactose four of the 17 patients had diarrhoea precipitated by the test with reducing substances in the stool. No patient had reducing substances in the stool on admission, however, so it is unlikely that lactose intolerance caused the diarrhoea then. Only three of the four lactose-intolerant patients could be retested after recovery but they had become tolerant of lactose. In these three patients acute measles had probably caused a temporary lactose intolerance.

Xylose absorption is impaired by systemic bacterial infections, ${ }^{12}$ so it is not surprising that it should be depressed during the acute stage of a systemic viral infection such as measles. Other viral infections caused by enteroviruses or herpes simplex virus are associated with diarrhoea, especially in underweight children, and are common precipitators of severe malnutrition. ${ }^{13}$ Possibly these infections are accompanied by gastrointestinal protein loss and malabsorption in the same way as measles.

This work was supported by the Medical Research Council, U.K., and the Paediatric Research Fund of Ahmadu Bello University, Zaria.

We thank Dr. Norman Veall for his technical advice and help, Miss Virginia Yewdall for help with biochemical measurements, and Mr. Peter Cheese for help with diagrams.

We are particularly grateful to Mr. G. F. Moss, manager of metabolic studies at Fisons Pharmaceuticals Ltd., for providing the ${ }^{59} \mathrm{Fe}-$ labelled iron dextran.

Requests for reprints should be addressed to J.F.B.D.

\section{References}

1 Morley, D., British Medical fournal, 1969, 1, 297.

2 Ogbeide, M. J., West African Medical fournal, 1971, 20, 313

3 Murphy, E. L., Ghana Medical fournal, 1966, 5, 58

4 Poskitt, E. M. E., Lancet, 1971, 2, 68.

5 Dossetor, J. F. B., Environment and Child Health, in publication.

World Health Organization, foint F.A.O./W.H.O. Expert Committee on Nutrition, 8th Report, Technical Report Series, No. 477, Geneva, W.H.O., 1971.

7 Jarnum, S., et al., Gastroenterology, 1968, 52, 229.

8 Trinder, P. Fournal of Clinical Pathology, 1969, 22, 246.

${ }^{9}$ Rolles, C. J., et al., Lancet, 1973, 2, 1043.

10 Rutishauser, I. H. E., Ecology Food and Nutrition, 1974, 3, 213.

11 Nelson, W. E., Vaughan, V. C., and McKay, R. J. (editors), Textbook of Pediatrics. Philadelphia, Saunders, 1969.

12 Cook, G. C., American fournal of Clinical Nutrition, 1972, 25, 490.

13 McKenzie, D., Archives of Disease in Childhood, 1959, 34, 250. 